\title{
IDEOLOGI KONSERVATISME DALAM PENDIDIKAN SENI MUSIK
}

\author{
Raafinsha Rahmaniar ${ }^{1}$, Mardi ${ }^{2}$ \\ Universitas Negeri Semarang ${ }^{1}$ \\ Raafinsha.r@gmail.com ${ }^{1}$ \\ Universitas Negeri Semarang ${ }^{2}$ \\ mardijhon75@gmail.com ${ }^{2}$
}

\begin{abstract}
Abstrak
Masuknya berbagai budaya baru di era modern menyebabkan menipisnya rasa cinta terhadap budaya tradisional yang dianggap kuno. Tujuan penulisan ini untuk mengatasi permasalahan masyarakat di era modern yang mulai meninggalkan nilai tradisional. Era modern yang ditandai dengan industrialisasi berdampak pula terhadap bentuk pendidikan. Bentuk pendidikan yang lebih mengutamakan kemapuan teknis-praktis sehingga mengorbankan nilai etis-humanistik. Bentuk pendidikan seperti itu mengakibatkan tereduksinya nilai-nilai kemanusiaan. Diperlukan suatu pendidikan yang bisa menumbuhkan kesadaran peserta didik untuk mencintai, menghormati, dan menghargai warisan budaya yang ada sehingga tidak hilang karena tergerus modernisasi. Pendidikan seni berideologi konservatisme merupakan jawaban atas permasalahan tersebut. Dalam pratiknya, pembelajaran seni dilakukan secara apresiasi dan kreasi seni pada nilai-nilai tradisional, yang bertujuan untuk menjaga dan melestarikan budaya yang telah ada, sehingga budaya tersebut tetap utuh meski di tengah derasnya arus modernisasi.
\end{abstract}

Kata kunci: konservatisme; musik; pendidikan musik

\begin{abstract}
The entry of various new cultures in the modern era led to the depletion of love for traditional cultures that were considered ancient. The purpose of this paper is to overcome the problems of society in the modern era which began to leave traditional values. The modern era which is marked by industrialization also fills the form of education. A form of education that prioritizes technical-practical abilities so as to sacrifice ethicalhumanistic values. This form of education results in the reduction of human values. An education is needed that can foster students' awareness to love, respect, and appreciate existing cultural heritage so that it is not lost because it has been eroded by modernization. Arts education with conservatism ideology is the answer to that problem. In practice, art learning is carried out in appreciation and artistic creations on traditional values, which aim to preserve and preserve existing culture, so that the culture remains intact even in the midst of the swift currents of modernization.
\end{abstract}

Keywords: convertism; music; music education

\section{Pendahuluan}

Pendidikan saat ini lebih cenderung ke arah pendidikan yang bersifat positivisme. Terbukti dengan konsep pembelajaran yang harus menggunakan pembelajaran berbasis Sains. Akibatnya segala macam pengetahuan harus melalui pendekatan sains untuk menunjukkan kebenarannya, sehingga jika tidak dapat dihitung dan dikalkulasikan secara matematis dianggap tidak benar.

Pendidikan semacam itu kiranya tidak cocok diterapkan oleh pelajaran ilmu sosial khususnya, dikarenakan ilmu sosial begitu kompleks yang tidak dapat dihitung secara 
matematik, sehingga dalam praktiknya pendidikan jatuh ditangan buku paket. Guru berpasrah terhadap apa yang sudah disediakan oleh pemerintah untuk menjalankan proses pendidikannya. Handook oriented merupakan langkah nyaman untuk menjalankan pendidikan berbasis Saintifik, sehingga bentuk pendidikan semakin menjauhkan anak terhadap realitas sosial dan anak cenderung hanya melihat realitas buku.

Adanya pasar bebas memberikan dampak yang nyata terhadap pendidikan di Indonesia, pendidikan saat ini berorientasi mencetak calon pekerja. Pendidikan terlepas dari hakikat pendidikan itu sendiri yaitu penggalian potensi yang dimiliki anak. Akibatnya anak semakin terjajah karena tuntutan yang tinggi dari sekolah. Disisi lain pengembangan kurikulum yang dilakukan pemerintah merupakan jawaban atas persoalan dunia kerja. Namun dalam praktiknya, kurikulum justru menambah masalah. Permasalahan tersebut diakibatkan karena ketidaksiapan guru terhadap perubahan kurikulum.

Persoalan tersebut menjadikan pelajaran terbagi menjadi dua kelompok yaitu pelajaran utama dan pelajaran pelengkap. Pelajaran utama yaitu pelajaran yang bersifat positivistik dan yang mampu memberi bekal untuk kerja. Pelajaran utama seperti ini biasanya ditandai dengan diikutsertakannya dalam ujian nasional (UN), sedangkan pelajaran lainya dianggap sebagai pelajaran formalitas saja. Padahal sebenarnya semua pelajaran sama pentingnya karena yang dibutuhkan anak bukan hanya kecerdasan intelektual saja melainkan sikap dan keterampilan.

Upaya untuk memecahkan kebuntuan permasalahan tersebut, pendidikan berbasis konservatisme merupakan alternatif dalam mengatasinya. Ideologi konservatis dalam pendidikan yaitu menggali kembali nilai-nilai tradisional yang telah teruji pada zamannya untuk dijadikan pondasi lagi disaat ini. Nilai merupakan seperangkat konsepsi yang dihayati oleh masyarakat mengenai apa yang penting atau bukan, apa yang baik atau kurang, dan apa yang benar atau kurang benar. Sedangkan tradisi berkaitan erat dengan kebiasaan yang sudah dilakukan secara turun-temurun, sehingga nilai tradisi merupakan semacam pedoman-pedoman dalam hidup bermasyarakat yang sudah berlangsung sejak lama.

Dalam pendidikan seni, ideologi konservatisme sangat relevan dengan Road map For Art Education Unesco yaitu Heritage, dan selaras dengan fungsi pendidikan seni yaitu sebagai bentuk pelestarian. Pelesatarian dalam konteks masalah ini melalui kesenian tradisional yang secara khusus dalam musik tradisional. Kesenian tradisional apapun bentuknya merupakan produk estetis simbolis masyarakat yang berakar pada pengalaman 
sosio-kultural-religius sehingga didalamnya terkandung kearifan dan nilai yang mulia. Nilai-nilai itu memiliki keragaman sesuai dengan dinamika masyarakat pendukungnya (Sutarto, 2004, p. 1).

\section{Asal Mula Ideologi Konservatisme}

Konservatisme berasal dari bahasa Inggris yaitu conservative yang kemudian diserap ke dalam bahasa Indonesia. Konservatisme adalah sebuah filsafat politik yang mendukung nilai-nilai tradisional. Istilah ini berasal dari kata dalam bahasa Latin, conservare, melestarikan, "menjaga, memelihara, mengamalkan". Karena berbagai budaya memiliki nilai-nilai yang mapan dan berbeda-beda, kaum konservatif di berbagai kebudayaan mempunyai tujuan yang berbeda-beda pula. Sebagian pihak konservatif berusaha melestarikan status quo, sementara yang lainnya berusaha kembali kepada nilainilai dari zaman yang lampau.

Samuel Francis mendefinisikan konservatisme yang otentik sebagai bertahannya dan penguatan orang-orang tertentu dan ungkapan-ungkapan kebudayaannya yang dilembagakan. Roger Scruton menyebutnya sebagai pelestarian ekologi sosial dan politik penundaan, yang tujuannya adalah mempertahankan, selama mungkin keberadaan sebagai kehidupan dan kesehatan dari suatu organisme sosial (Kristeva, 2010, p. 82).

Meskipun konservatisme adalah suatu pemikiran politik namun sejak awal, ia mengandung banyak alur yang kemudian dapat diberi label konservatif, baru pada masa Penalaran, dan khususnya reaksi terhadap peristiwa-peristiwa di sekitar Revolusi Perancis pada tahun 1789, konservatisme mulai muncul sebagai suatu sikap atau alur pemikiran yang khas. Banyak orang yang mengusulkan bahwa bangkitnya kecenderungan konservatif sudah terjadi lebih awal yaitu pada masa-masa awal Reformasi, khususnya dalam karyakarya teolog Anglikan yang berpengaruh, Richard Hooker yang menekankan pengurangan dalam politik demi menciptakan keseimbangan terhadap berbagai kepentingan menuju keharmonisan sosial dan kebaikan bersama. Namun baru ketika polemik Edmund Burke muncul-Reflections on the Revolution in France-konservatisme memperoleh penyaluran pandangan-pandangannya yang paling berpengaruh (Kristeva, 2010). Ideologi konservatif hakikatnya bertujuan untuk mengembalikan tatanan kehidupan berdasarkan nilai-nilai tradisi budaya yang telah teruji dapat menyejahterakan rakyat.

Menurut Hearnshaw sebagaimana dikutip oleh (F. O'neil, 2001, p. 297) dalam bukunya yang berjudul ideologi-ideologi pendidikan bahwa terdapat dua belas prinsip 
dasar dalam ideologi konservatime yaitu penghormatan terhadap masa silam, konsepsi organis mengenai masyarakat, kesatuan komunal, keberlanjutan kostitusional, menentang revolusi, pembaharuan/ reformasi yang hati-hati secara evolusioner, landasan keagamaan bagi negara, sumber keTuhanan bagi wewenang yang absah, mendahulukan kewajiban daripada hak, watak individu dan karakter komunal adalah hal yang sangat penting, kesetiaan/ loyalias, dan yang terakhir yaitu akal sehat, realisme, dan kepraktisan.

Secara substantif, ideologi konservatif pada hakikatnya ingin mengembalikan tatanan kehidupan berdasarkan nilai-nilai tradisional lama yang telah teruji dapat menyejahterakan masyarakat (Triyanto, 2017, p. 18). Nilai-nilai ini biasanya sudah menjadi bagian hidup di masyarakat dengan bentuk egaliternya. Selain itu nilai-nilai tradisional berkaitan langsung dengan religiusitas yang dijadikan pedoman untuk hidup bersama.

\section{Konsep Pendidikan Seni}

Istilah pendidikan seni di dalamnya terdapat dua konsep yang dijadikan satu kesatuan antara konsep pendidikan dan konsep seni. Dari segi kebahasaan setiap orang tidaklah mungkin keliru mengartikan pendidikan dan seni, namun ketika dua istilah tersebut dijadikan satu sehingga membentuk konsep baru tentunya akan menghasilkan peristilahan baru. Dengan demikian tidaklah cukup hanya memahami secara literal saja, namun diperlukan pemahaman yang substansial.

Pendidikan seni dalam konteks pendidikan secara lebih luas, seperti dideklarasikan dalam konvensi internasional tahun 2006 ditujukan untuk memastikan setiap anak dan orang dewasa mendapatkan hak untuk memperoleh dan mendapatkan peluang untuk terlibat dalam pembangunan dan keikutsertaan dalam bidang kebudayaan dan artistik secara menyeluruh dan seimbang. Hal tersebut merupakan sebuah pondasi yang kuat bahwasannya setiap individu memiliki hak untuk mendapatkan pendidikan seni, baik kelompok minoritas hingga kelompok yang berkebutuhan khusus (Wuryanto, Rohidi, \& Tarwiyah, 2016).

Pendidikan seni secara umum merupakan upaya sadar untuk menyiapkan siswa melalui kegiatan pembimbingan, pembelajaran, dan pelatihan agar siswa memiliki kemampuan berkesenian (Jazuli, 2008, p. 15). Kemampuan berkesenian di sini terkait dengan kompetensi keseniman dan kompetensi sebagai bentuk pengalaman belajar dalam rangka pendewasaan potensi individu untuk membentuk manusia seutuhnya. Hal senada 
juga diungkapkan oleh Rohidi (2011, p. 57) bahwa pendidikan seni merupakan bagian dari pendidikan umum — seperti juga pendidikan lainnya — di sekolah umum, yang melalui berbagai kegiatan dalam proses pengajaran dan pembelajarannya yang diharapkan dapat memacu murid ke arah kedewasaannya sebagai manusia yang bermartabat.

Soehardjo dalam bukunya yang berjudul "pendidikan seni dari konsep sampai progam", menjelaskan bahwa pendidikan seni merupakan usaha sadar untuk menyiapkan peserta didik melalui kegiatan bimbingan, pengajaran atau latihan agar mempunyai kemampuan berkesenian sesuai dengan peran yang harus dimainkan, sedangkan peran yang dimainkan dalam konteks ini yaitu penularan dan pemfungsian seni (Harwanto, 2018; Soehardjo, 2012).

Pendidikan seni yang memiliki konsep penularan seni tidak semata-mata hanya menularkan kemampuan berkesenian yang bersifat fisik namun sekaligus penularan filosofinya (Soehardjo, 2012, p. 17). Karena dengan belajar filosofinya diharapkan dapat membentuk seorang seniman yang matang setelah proses pembelajarannya selesai/ lulus. Konsep penularan seni ini dapat dilakukan di lembaga formal, non-formal dan informal. Dalam pendidikan formal dapat ditemukan di lingkup sekolah kejuruan seni, pendidikan non-formal dapat dijumpai pada sanggar seni atau komunitas seni, sedangkan pendidikan informal dilakukan di lingkungan keluarga.

Dalam pendidikan formal tingkat pendidikan atas, konsep pendidikan penularan seni cocok diterapkan pada lembaga pendidikan sekolah kejuruan seni. Sekolah kejuruan seni merupakan lembaga pendidikan formal yang mengakomodasi peserta didik menjadi calon seniman. Lulusan sekolah kejuruan seni dapat langsung terjun ke masyarakat atau melanjutkan pendidikan seni tinggi yang relevan. Implementasi dalam pembelajaran dikemas secara bertahap sedemikian rupa, sesuai dengan kurikulum acuannya. Suatu tahapan tertentu tidak dapat diikuti oleh pembelajar yang belum menguasai keterampilan di tahap sebelumnya. Dengan demikian penguasaan keterampilan seni merupakan hal yang sangat penting dalam konsep penularan seni.

Konsep pemfungsian seni memiliki arti bahwa keberadaan seni dengan segala karakteristiknya yang melekat padanya dapat dimanfaatkan untuk dilibatkan dalam usaha mempersiapkan calon masyarakat, generasi baru yang dijadikan tumpuan harapan bagi bangsa dan negara ke depan (Soehardjo, 2012, p. 31). Pendekatan pemfungsian seni harus menganut seni sebagai sarana untuk menumbuhkembangkan pelajar melalui seni. Oleh karena itu, kemudian pendidikan seni menjadi salah satu mata pelajaran di sekolah, dengan 
tujuan utama menyiapkan pelajar sebagai pribadi yang utuh, sehat jasmani dan rohani, dan mampu mengembangkan potensi masing-masing peserta didik.

Dengan melihat kedua konsep tersebut maka jelaslah bahwa pendidikan seni memiliki tujuan yang berbeda. Tujuan pendidikan seni dapat dibagi menjadi dua berdasarkan lembaga pendidikannya yaitu lembaga pendidikan vokasional dan lembaga pendidikan umum (avokasional). Tujuan pendidikan seni di lembaga vokasional adalah siswa dituntut untuk menguasai keterampilan seni, sedangkan dalam pendidikan umum yaitu bertujuan untuk mencapai tujuan pendidikan yang dalam pelaksanaannya lebih menekankan pada proses belajar. Sehingga penekanannya yaitu seni sebagai wahana untuk berekspresi, berimajinasi, berkreasi sekaligus berkreasi.

\section{Konservatisme dalam Pendidikan}

Konservatisme pendidikan berakar dari konservatisme politik yang mendukung ketaatan terhadap lembaga-lembaga dan proses-proses budaya yang sudah teruji oleh waktu. Paham konservatisme menyebutkan bahwa berpegang teguh pada tradisi yang telah terbukti berhasil di masa lalu merupakan hal terbaik yang dapat dilakukan. Hal ini bertujuan untuk menjaga keadaan yang dinamis dan statis.

Bagi kaum konservatif, sasaran pendidikan adalah sebagai pelestarian dan penerusan pola-pola kemapanan sosial serta tradisi-tradisi. Konservatisme pendidikan menganggap bahwa nilai dasar pengetahuan ada pada kegunaan sosialnya (F. O'neil, 2001). Paham konservatisme menganggap bahwa intelektual tertinggi adalah budaya dominan dengan segenap sistem keyakinan dan perilakunya yang mapan. Perubahan dalam pendidikan diperbolehkan, asalkan tidak menyimpang dari sistem yang telah dianut sebelumnya.

Kesamaan-kesamaan individual lebih penting ketimbang perbedaan-perbedaannya dan kesamaan-kesamaan itu menentukan dalam menetapkan program-program pendidikan yang tepat. Anak-anak secara moral memiliki kesempatan yang sama di dalam dunia objektif yang tak setara, mereka harus memiliki kesempatan yang setara untuk mengejar sejumlah ganjaran terbatas yang tersedia. Namun keberhasilan harus dikondisikan berdasarkan prestasi kebaikan personal. Seorang anak pada intinya menentukan nasibnya sendiri dan ia memiliki kehendak bebas personal dalam arti yang tradisional. 


\section{Pendidikan Seni Musik Konservatisme}

Pendidikan merupakan proses memanusiakan manusia menjadi makhluk yang berbudaya. Pendidikan bertujuan untuk membentuk manusia yang utuh, yang tidak hanya terpaku pada pengembangan aspek kognitif, namun juga aspek afektif dan psikomotor. Sebagai tujuan akhir, pendidikan yang baik hendaknya berorientasi pada pembentukan karakter peserta didik. Salah satu pendidikan yang dianggap mampu mengoptimalkan ketiga aspek tersebut ialah pendidikan seni, khususnya seni musik.

Salah satu ciri ideologi konservatisme adalah berorientasi ke masa kini dan para pendidik konservatif sangat menghormati masa silam, namun memusatkan perhatiannya pada kegunaan serta pola belajar-mengajar di dalam konteks sosial yang sedang terjadi sekarang. Lebih lanjut O'neil menyebutkan bahwa terdapat dua ungkapan dasar dalam konservatisme pendidikan yaitu konservatisme pendidikan sekuler dan konservatisme pendidikan religius (F. O’neil, 2001).

Konservatisme pendidikan sekuler terfokus pada pengembangan pengetahuan dan keterampilan yang diperlukan individu, agar mampu bertahan hidup — dalam lingkungan sosial. Sedangkan konservatisme pendidikan religius memiliki pandangan yang sama dengan konservatisme sekuler, namun dengan lebih menekankan pada aspek keTuhanan. Konservatisme pendidikan religius meyakini bahwa pelatihan rohaniah merupakan aspek dasar dalam tradisi sosial yang mapan, yang layak dan penting bagi pendidikan dasar seorang anak. Dua ungkapan dasar itu, dapat ditemukan dalam pendidikan musik. Pada pendidikan seni musik konservatisme pendidikan sekuler tercermin pada dipelajarinya teori musik serta pembelajaran keterampilan bermain musik, sedangkan pada pendidikan konservatisme religius tercermin pada pembelajaran musik-musik rohani, seperti musik gereja dan rebana.

Dalam praktik pendidikan di sekolah, pendidikan seni dilakukan dengan dua kegiatan yaitu apresiasi dan kreasi. Apresiasi merupakan kegiatan menilai/ menanggapi hasil karya orang lain. Apresiasi dapat dilakukan melalui kegiatan mengamati, memahami, dan menghayati. Sikap apresiatif tidak semata-mata muncul, namun diperlukan kesadaran dari pihak apresiator untuk melihat secara lebih mendalam tentang karya yang diapresiasi. Tindakan untuk mengapresiasi suatu karya memunculkan pengalaman estetik. Pengalaman estetik merupakan pengalaman khusus yang diakibatkan dari seseorang melakukan kontak secara langsung dengan keindahan, dalam hal ini ialah suatu karya seni. 
Sikap apresiatif merupakan modal budaya dalam memelihara sistem kesenian. Eksistensi seni dapat tetap hidup dalam lingkungan sosialnya dikarenakan terjadi dialog estetik antara kreator dan apresiator, dengan karya seni sebagai medianya (Triyanto, 2017). Pembelajaran apresiasi merupakan bentuk kongkrit dari dialog antara kreator dan apresiator. Dalam konteks pembelajaran di kelas, kreator diwakili oleh guru dan apresiator diwakili oleh siswa, sedangkan karya seninya sebagai media supaya dialog itu terjadi. Kegiatan apresiasi dilakukan untuk memelihara dan mempertahankan suatu karya tradisional melalui pendidikan seni-khususnya seni musik-yang salah satunya dapat dilakukan dengan cara mengapresiasi lagu daerah Nusantara.

Lagu daerah merupakan lagu yang lahir dan berkembang di daerah tertentu dan diwariskan secara turun temurun, namun tidak semua orang dapat mengerti makna dari lagu daerah karena liriknya menggunakan bahasa lokal daerah setempat. Ciri-ciri lagu daerah diantaranya bersifat kedaerahan, memiliki notasi yang sederhana, jarang diketahui penciptanya, serta diwariskan secara turun temurun. Meskipun sederhana, lagu daerah memiliki makna yang mendalam. Lagu daerah mengandung nilai-nilai kehidupan, unsurunsur kebersamaan sosial, serta keserasian dengan lingkungan hidup sekitar yang dapat dijadikan patokan dalam berperilaku di dalam kehidupan.

Sayangnya, seiring perkembangan zaman, kecintaan terhadap hal-hal yang bersifat tradisional semakin memudar, tidak terkecuali lagu daerah. Hal ini dikarenakan lagu daerah dianggap kuno. Selain itu perkembangan budaya modern dan globalisasi yang dikemas dalam berbagai bentuk media komunikasi dan informasi turut memengaruhi berkurangnya apresiasi masyarakat terhadap keberadaan kesenian tradisional seperti lagu yang bersifat kedaerahan. Hal tersebut dipertegas dengan pendapat Abidin (2018) bahwa modernisasi telah mengesampingkan kepentingan tradisionalisme yang terbelakang, kaku, dan pemborosan. Dengan demikian, jika kondisi tersebut dibiarkan begitu saja maka tidak menutup kemungkinan bahwa generasi selanjutnya tidak akan mengetahui bahwa Indonesia 'kaya' dengan kesenian tradisi.

Kegiatan mengapresiasi lagu daerah dapat menumbuhkan rasa cinta terhadap daerahnya. Dengan berusaha mengamati, memahami, dan menghayati isi lagu, siswa secara sadar maupun tidak sadar telah memberikan atensi khusus terhadap suatu karya. Lambat laun hal ini akan memunculkan sikap menghargai. Kegiatan apresiasi memiliki pengaruh yang cukup besar dikarenakan beberapa alasan antara lain 1) mengajak siswa tidak hanya mengenal, melainkan bertemu langsung, mendengarkan dan memainkan alat 
musik sehingga menimbukan rangsangan bagi kemampuan siswa; 2) pelibatan peserta didik dalam pembelajaran lebih aktif, karena mereka mencari informasi mengenai makna dan tujuan seni di lingkungan masyarakat; 3) pembelajaran yang dilakukan dapat melampaui apa yang ditargetkan dalam kurikulum - perluasan kesempatan memperoleh informasi; dan 4) pembelajaran lebih aktif dan interaktif, karena lebih terpusat kepada pelibatan peserta didik secara optimal dalam kondisi yang kondusif (Putra, 2014, p. 9). Salah satu tujuan pembelajaran apresiasi seni adalah menumbuhkan rasa cinta siswa dan sikap menghargai budayanya sendiri. Dengan demikian, budaya yang ada akan tetap lestari tanpa tergerus arus modernisasi.

Pendidikan seni mengintegrasikan kemampuan fisik, intelektual, kreativitas, serta mempertautkan pendidikan, kebudayaan, dan kesenian secara lebih dinamis dan bermakna (Rohidi, 2014, p. 9). Selain proses apresiasi, konservatisme dalam pendidikan seni juga dilakukan melalui proses berkreasi. Menurut Kamus Besar Bahasa Indonesia, kreasi berarti hasil daya cipta kecerdasan akal manusia. Kreasi berhubungan erat dengan kreativitas. Kreativitas merupakan suatu pola pikir atau kegiatan di mana seseorang mencoba mengembangkan sesuatu, baik yang sudah ada maupun hal baru. Kreativitas dapat didasari dari terinspirasi akan sesuatu yang ada dan mendasar maupun sebuah ide-ide baru yang terlintas di pikiran. Pengembangan dapat menciptakan akulturasi maupun asimilasi. Inti dari kreativitas menurut Campbell adalah mampu menemukan kebaruan dan mampu mengatasi masalah dengan gemilang. Dalam kreativitas inilah pribadi seseorang selalu berpikiran positif untuk menemukan hal yang baru dengan menciptakan proses (sistem) dan produk. Kesemuanya ini nantinya akan menemukan konsep atau cita kreatif pada seseorang (Sunarto, 2018, p. 2).

Pada dasarnya terdapat dua proses kreatif yaitu kreativitas artistik-proses penciptaan — dan kreativitas estetik atau proses penghayatan. Kreativitas dapat terjadi di beberapa bidang, antara lain (a) kegiatan ide, kegiatan berpikir, kegiatan berangan-angan, dan kegiatan berkhayal (fantasi); (b) kegiatan berekspresi, kegiatan pernyataan artistik, atau visual; (c) kegiatan kerja fisik yang akan melaksanakan dan membuktikan kebenaran ide yang telah dikarangnya (Soetjipto, 1989, p. 40).

Kegiatan pengembangan pembelajaran lagu daerah Nusantara dapat dituangkan dalam bentuk penyusunan aransemen lagu. Aransemen merupakan kegiatan kreatif dalam mengolah dan mengembangkan elemen-elemen musik menjadi sebuah karya baru. Terdapat tiga jenis aransemen yaitu aransemen vokal, instrumental, serta gabungan dari 
keduanya. Siswa berkreasi seperti membuat pembagian suara pada lagu, bahkan dapat pula pengubahan genre lagu. Selain sebagai sarana pengembangan kreativitas siswa, kegiatan ini bertujuan untuk menciptakan suasana lagu yang baru dan lebih menarik. Guru diharapkan tidak membatasi kreativitas penggubahan lagu, selama aransemen lagu yang baru tidak 'menenggelamkan' lagu aslinya.

Pada intinya, kegiatan apresiasi dan kreasi seni bertujuan agar siswa mengenal dan mengetahui bahwa terdapat beragam lagu daerah yang unik serta dapat meningkatkan kecintaan terhadap warisan budaya Nusantara. Siswa merasa memiliki dan berusaha untuk dapat memelihara, melestarikan, serta terus mengembangkan budayanya sendiri, sehingga semangat siswa dalam pendidikan seni selaras dengan semangat ideologi konservatisme.

\section{Kesimpulan}

Konservatisme diartikan sebagai ideologi dan filsafat yang menjunjung tinggi nilainilai tradisional. Dalam pendidikan, ideologi konservatisme berorientasi pada nilai-nilai dan norma budaya yang telah ada untuk dijadikan landasan penyelenggaraan pendidikan. Ideologi konservatisme dalam pendidikan seni tercermin dalam dua pendekatan yaitu pendidikan melalui seni dan pendidikan dalam seni. Pada pendidikan seni musik, ideologi konservatisme terejawantah dalam pembelajaran tentang lagu daerah Nusantara. Selain karena lagu daerah Nusantara memiliki makna serta nilai yang mendidik, pembelajaran lagu daerah juga diterapkan sebagai bentuk upaya pelestarian budaya. Dengan demikian melalui ideologi konservatisme dalam pendidikan seni, nilai adiluhung dalam kesenian tradisional dapat terjaga dengan baik, meskipun digempur dengan arus moderenisasi yang tidak dapat dihindari.

\section{Kepustakaan}

Abidin, Y. S. (2018). Filsafat Postmoderen. Bandung: Pustaka Setia.

F. O’neil, W. (2001). Ideologi-Ideologi Pendidikan. Yogyakarta: Pustaka Pelajar.

Harwanto, D. C. (2018). Memaknai Inkulturasi Dalam Pendidikan Seni Dan Konservasi. Tonika: Jurnal Penelitian Dan Pengkajian Seni, 1(1), 40-50. Retrieved from http://journal.stt-abdiel.ac.id/tonika/article/view/10

Jazuli, M. (2008). Paradigma Kontekstual Pendidikan Seni. Surabaya: Unesa University press.

Kristeva, N. S. (2010). Sejarah Ideologi Dunia: Eye on The Revolution Press Institute for Philosophycal and Social Studies (INPHISOS). 
Kristeva, Nur Sayyid. (2010). Sejarah Ideologi Dunia: Eye on The Revolution Press Institute for Philosophycal and Social Studies (INPHISOS).

Putra, I. N. J. dkk. (2014). Pengaruh aktivitas Pembelajaran Apresiasi Seni Terhadap Pemahaman Siswa Mengenai Seni Karawitan Ditinjau dari Kemampuan Artistik Siswa di SMA Negeri 1 Semarapura. E-Journal Program Pascasarjana Universitas Pendidikan Ganesha, 4, 1-11.

Rohidi, T. R. (2011). Metode Penelitian Seni. Semarang: Cipta Prima.

Rohidi, T. R. (2014). Pendidikan Seni Isu dan Paradigma. Semarang: Cipta Prima Nusantara.

Soehardjo, A. J. (2012). Pendidikan Seni: dari Mulai Konsep Sampai Program Buku Satu. Malang: Banyumedia Publishing.

Soetjipto, K. (1989). Sejarah Perkembangan Seni Lukis Modern Jilid 1.

Sunarto. (2018). Pengembangan Kreativitas-Inovatif Dalam Pendidikan Seni. Refleksi Edukatika, 8(2).

Sutarto, A. (2004). Menguak Pergumulan Antara Seni, Politik, Islam, dan Indonesia. Jawa Timur: Kompyawisda.

Triyanto. (2017). Spirit Ideologis Pendidikan Seni. Semarang: Cipta Prima Nusantara.

Wuryanto, Rohidi, T. R., \& Tarwiyah, T. (2016). Yen Ing Tawang Ana Lintang: Kasus Bentuk Musik Keroncong Group Congrock 17 Di Semarang. Catharsis, 5(2), 79-83. 